\title{
KUALITAS SILASE RUMPUT ODOT (Pennisetum purpureum cv.Mott) DENGAN PENAMBAHAN Lactobacillus plantarum DAN MOLASSES PADA WAKTU INKUBASI YANG BERBEDA
}

\author{
The Quality of Dwarf Elephant Grass (Pennisetum purpureum cv.Mott) \\ Silage using Lactobacillus plantarum and Molasses with \\ Different Incubation Time \\ Wiwik Srilidiya Wati $^{1)}$, Mashudi ${ }^{2)}$ dan Artharini Irsyammawati ${ }^{2)}$ \\ 1) Mahasiswa Fakultas Peternakan, Universitas Brawijaya, Malang-65145, Indonesia \\ ${ }^{2)}$ Dosen Minat Nutrisi dan Makanan Ternak, Fakultas Peternakan, Universitas Brawijaya, Malang-65145, \\ Indonesia \\ Email: artharini_19@ub.ac.id
}

\begin{abstract}
ABSTRAK
Tujuan dari penelitian ini adalah untuk mengetahui pengaruh dari waktu inkubasi pada silase rumput odot (Pennisetum purpureum cv.Mott) dengan penambahan molasses dan Lactobacillus plantarum sebagai starter pada kualitas fisik, pH, dan kandungan nutrisi. Materi yang digunakan yaitu rumput odot, molasses 6\%, dan bakteri Lactobacillus plantarum 0,6\%. Metode penelitian yang digunakan yaitu Rancangan Acak Lengkap (RAL) dengan 4 perlakuan dan 3 ulangan. Setiap perlakuan terdiri dari rumput odot $+6 \%$ molasses $+0,6 \%$ Lactobacillus plantarum dengan waktu inkubasi yang berbeda. Waktu inkubasi yang digunakan yaitu PO (0 hari), P1 (7 hari), P2 (14 hari) dan P3 (21 hari). Variabel yang diamati yaitu kualitas fisik (warna, tekstur, aroma dan keberadaan jamur), pH, kandungan nutrisi (bahan kering, bahan organik, protein kasar, serat kasar dan lemak kasar) dan nilai fleigh. Data dianalisis dengan Analysis of Variance (ANOVA) dan jika ada perbedaan secara nyata dilanjutkan dengan Uji Jarak Berganda Duncan (UJBD). Hasil penelitian ini menunjukkan bahwa perlakuan memberikan pengaruh sangat nyata terhadap aroma, tekstur, lemak kasar, $p H$ dan nilai fleigh, tetapi memberikan pengaruh nyata terhadap serat kasar dan tidak berpengaruh terhadap warna, bahan kering, bahan organik dan protein kasar. Kesimpulandaripenelitianiniadalahdengan waktu inkubasi 7 hari (P1) memiliki karakteristik fisik (warna, aroma dan tekstur) silase yang baik, $p H$ yang rendah ( $p H$ 4,10) serta penurunan kandungan nutrisi yang rendah (BK 15,69\%, BO 82,44\%, PK 11,81\%, SK $23,74 \%$ dan $L K 2,23 \%)$.
\end{abstract}

Kata kunci: Kandungan nutrisi; karakteristik fisik;rumput odot; silase; waktu inkubasi

How to Cite :

Wati, W.S (2018). Pengaruh Penggunaan Tepung Biji Kemiri dalam Pakan Terhadap Kinerja Reproduksi Burung Puyuh (Coturnix coturnix japonica). Jurnal Nutrisi Ternak Tropis, 1 (1) 45-53
*Corresponding author:

Wiwik Srilidiya Wati

Email : artharini_19@ub.ac.id

Faculty of Animal Science, Brawijaya University, Veteran Street, Malang, East Java, Indonesia. 65145 


\section{ABSTRACT}

The objective of this research was to evaluate the effect of incubation time on dwarf elephant grass (Pennisetum purpureum cv.Mott) silage using additional of molasses and Lactobacillus plantarum as starter on physical quality, $\mathrm{pH}$, and nutritional value. The material used was dwarf elephant grass, molasses 6\%, and Lactobacillus plantarum bacteria $0.6 \%$. The research method used was completely randomized design (CRD) with four treatments and three replications. Each treatment consists of dwarf elephant grass $+6 \%$ molasses $+0.6 \%$ Lactobacillus plantarum with difference incubation time. The incubation time were $T 1$ (0 day), T2 (7 days), T3 (14 days) and T4 (21 days). The research variables were physical quality (color, texture, smell and existence of fungi), $\mathrm{pH}$, nutritional value (dry matter, organic matter, crude protein, crude fiber, crude fat) and fleigh point. Data were analyze using Analysis Of Variance (ANOVA) and if there were any significant difference would be continued with Duncan's Multiple Range Test (DMRT). The results showed that the treatment gave highly significant effect on smell, texture, crude fat, $p H(4.10 \pm 0.10)$, and fleigh point $(72.37 \pm 3,68)$, but it gave significant effect on crude fiber and gave no effect on color, dry matter, organic matter and crude protein. So, it can be concluded that the best treatment was $T 1$ (7 days).

Keywords: Dwarf elephant grass; incubation time; nutritional content; physical characteristic; silage

\section{PENDAHULUAN}

Silase merupakan upaya pengawetan hijauan segar dengan metode fermentasi dan dalam kondisi anaerob dengan tujuan untuk menambah daya simpan hijauan sehingga dapat dimanfaatkan dalam waktu yang lama terutama pada saat musim kemarau. Selain itu, silase juga dimanfaatkan pada saat terdapat kelebihan produksi pada musim penghujan sehingga kelebihan produksi tidak terbuang percuma.

Prinsip pembuatan silase adalah fermentasi hijauan oleh mikroba yang banyak menghasilkan asam laktat dalam keadaan anaerob (Naif, Nahak, dan Dethan, 2015). Salah satu jenis bakteri asam laktat yang baik digunakan sebagai aditif dalam silase adalah Lactobacillus plantarum. Bakteri ini ditambahkan dengan tujuan untuk mempercepat proses penurunan $\mathrm{pH}$ silase. Rendahnya $\mathrm{pH}$ akan dapat meningkatkan daya simpan dari silase tersebut, sehingga diharapkan silase dapat bertahan lebih lama jika disimpan. Saat hijauan di ensilase, BAL akan meningkat jumlahnya dan memfermentasi water soluble carbohydrate (WSC) menjadi asam organik serta menghambat pertumbuhan bakteri lain. Pada $\mathrm{pH} \mathrm{3,8-}$ 4,0 aktivitas mikroba akan berhenti dan material yang di ensilase menjadi stabil. Selain bakteri asam laktat, bahan aditif lainnya yang biasa di tambahkan pada silase yaitu molasses. Molasses berguna sebagai sumber karbohidrat mudah larut atau WSC (Chalisty, Utomo dan Bachruddin, 2017).

Rumput odot (Pennisetum purpureum cv.Mott) merupakan salah satu jenis rumput yang unggul dan memiliki produktivitas serta kandungan nutrisi yang cukup tinggi. Rumput odot memiliki ukuran yang lebih kecil daripada jenis rumput gajah yang lainnya. Rumput odot dapat tumbuh di berbagai jenis tanah serta sangat responsif terhadap pemupukan. Rumput odot merupakan rumput yang tumbuh berumpun dan terus-menerus menghasilkan anakan jika dilakukan pemangkasan secara teratur. Produksi yang berlimpah dan kandungan nutrisi yang cukup tinggi di banding jenis rumput gajah yang lainnya membuat rumput odot berpotensi untuk dijadikan pakan ternak dalam berbagai bentuk, seperti silase. 


\section{MATERI DAN METODE}

Penelitian ini dilaksanakan pada 5 Juli 2017 sampai dengan 17 September 2017. Pelaksanaan pembuatan silase rumput odot, analisa fisik, $\mathrm{pH}$, serta analisis proksimat dilakukan di Laboratorium Nutrisi dan Makanan Ternak Fakultas Peternakan Universitas Brawijaya. Bahan yang digunakan yaitu rumput odot dengan umur panen 50 hari yang diperoleh dari peternakan Agriranch, Karangploso, Batu. Molasses yang berasal dari toko pertanian, bakteri Lactobacillus plantarum yang berasal dari laboratorium Nutrisi dan Makanan Ternak Fakultas Peternakan Universitas Brawijaya serta seperangkat bahan untuk analisa PK, SK dan LK. Peralatan yang digunakan yaitu seperangkat alat pembuatan silase, $\mathrm{pH}$ meter, seperangkat alat analisis $\mathrm{BK}, \mathrm{BO}$, PK, SK dan LK. Metode penelitian yang digunakan adalah percobaan Rancangan Acak Lengkap (RAL) dengan 4 perlakuan dan 3 ulangan. Susunan perlakuan yang digunakan adalah P0: Silase Rumput odot + $0,6 \%$ bakteri Lactobacillus plantarum + $6 \%$ Molasses, waktu inkubasi 0 hari, P1: Silase Rumput odot $+0,6 \%$ bakteri Lactobacillus plantarum $+6 \%$ Molasses, waktu inkubasi 7 hari, P2: Silase Rumput odot $+0,6 \%$ bakteri Lactobacillus plantarum $+6 \%$ Molasses, waktu inkubasi 14 hari dan P3: Silase Rumput odot $+0,6$ $\%$ bakteri Lactobacillus plantarum $+6 \%$ Molasses, waktu inkubasi 21 hari. Variabel penelitian yaitu karakteristik fisik (warna, aroma, tekstur, jamur), $\mathrm{pH}$, kandungan nutrisi $(\mathrm{BK}, \mathrm{BO}, \mathrm{PK}, \mathrm{SK}, \mathrm{LK})$ dannilai fleigh.Data yang diperoleh diolah menggunakan MS.Excel dengan analisis statistik menggunakan Analysis of Variance (ANOVA) dan jika ada perbedaan secara nyata dilanjutkan dengan Uji Jarak Berganda Duncan (UJBD).

\section{HASIL DAN PEMBAHASAN}

\section{Analisis Kandungan Nutrisi Rumput Odot}

Rumput odot yang digunakan sebagai bahan baku silase yaitu rumput odot dengan umur potong 50 hari yang masih dalam tahap pertumbuhan vegetatif sehingga kandungan nutrisinya masih tinggi.

Tabel 1. Kandungan nutrisi rumput odot

\begin{tabular}{cc}
\hline Nutrisi & $\begin{array}{c}\text { Kandungan nutrisi } \\
(\%)\end{array}$ \\
\hline BK & 16,59 \\
BO & $82,81^{*}$ \\
PK & $12,72^{*}$ \\
SK & $32,35^{*}$ \\
LK & $2,28^{*}$
\end{tabular}

Sumber: Hasil analisis Laboratorium Nutrisi dan Makanan Ternak Fakultas Peternakan Universitas Brawijaya (2017)

*) berdasarkan $100 \% \mathrm{BK}$

\section{Karakteristik Fisik Silase Rumput Odot}

Silase yang baik salah satunya dapat dilihat dari karakteristik fisik silase tersebut. Parameter penilaian karateristik fisik diantaranya yaitu warna, tekstur, aroma dan keberadaan jamur. Rataan hasil kualitas fisik silase rumput odot dengan waktu inkubasi yang berbeda $(0,7,14,21$ hari) dapat dilihat pada Tabel 2.

Tabel 2. Rataanhasilkualitasfisiksilaseodotpadamasing-masingperlakuan

\begin{tabular}{ccccc}
\hline Perlakuan & Warna & Tekstur & Aroma & Jamur \\
\hline P0 & $3,95 \pm 0,72$ & $3,32^{\mathrm{a}} \pm 0,75$ & $3,90^{\mathrm{b}} \pm 0,73$ & $5 \pm 0,00$ \\
P1 & $3,90 \pm 0,71$ & $3,38^{\mathrm{a}} \pm 0,74$ & $4,02^{\mathrm{b}} \pm 0,83$ & $5 \pm 0,00$ \\
P2 & $3,83 \pm 0,87$ & $3,63^{\mathrm{ab}} \pm 0,76$ & $3,12^{\mathrm{a}} \pm 0,74$ & $5 \pm 0,00$ \\
P3 & $3,82 \pm 0,77$ & $3,80^{\mathrm{b}} \pm 0,84$ & $3,02^{\mathrm{a}} \pm 0,70$ & $5 \pm 0,00$ \\
\hline
\end{tabular}

${ }^{* a-b}$ superskrip yang berbeda pada kolom rataan tekstur dan aroma menunjukkan perbedaan yang sangat nyata $(\mathrm{P}<0,01)$ 
Tabel 2 menunjukkan bahwa rataan terhadap karakteristik warna silase rumput odot dengan waktu inkubasi $0,7,14$ dan 21 hari berturut-turut yaitu $\mathrm{P0}(3,95 \pm 0,72)$, $\mathrm{P} 1(3,90 \pm 0,71), \mathrm{P} 2(3,83 \pm 0,87)$, dan $\mathrm{P} 3$ $(3,82 \pm 0,77)$ dimana semua perlakuan menghasilkan warna hijau kecoklatan dan perlakuan dengan inkubasi 0 hari cenderung lebih baik. Hal tersebut diduga lama fermentasi menyebabkan warna silase berubah dari warna asal yaitu hijau menjadi hijau kecoklatan. Kaiser dan Piltz (2004) menyatakan bahwa warna hijau cerah sampai hijau kecoklatan merupakan warna normal untuk silase rerumputan, biji-bijian, dan jagung, sedangkan warna hijau pucat atau kuning kecoklatan merupakan warna normal untuk silase rumput yang dilayukan. Menurut Hidayat (2014) silase yang baik memiliki warna coklat terang atau kekuningan dan memiliki bau yang asam.

Tabel 2 menunjukkan bahwa hasil rataan tekstur silase rumput odot memberikan pengaruh yang sangat nyata. Rataan tekstur silase rumput odot (Pennisetum purpureum cv.Mott) berturutturut dari yang terbaik yaitu $\mathrm{P} 3\left(3,80^{\mathrm{b}} \pm\right.$ $0,84), \mathrm{P} 2\left(3,63^{\mathrm{ab}} \pm 0,76\right), \mathrm{P} 1\left(3,38^{\mathrm{a}} \pm 0,74\right)$, dan P0 $\left(3,32^{\mathrm{a}} \pm 0,75\right)$. Hasil tersebut menunjukkan bahwa silase dengan waktu inkubasi $0,7,14$ dan 21 hari memiliki karakteristik tekstur sedikit keras serta tidak terdapat penggumpalan. Tekstur silase dipengaruhi oleh kadar air pada hijauan tersebut. Proses fermentasi yang singkat menyebabkan kadar air silase tidak terlalu tinggi, sehingga tekstur silase sedikit keras. Tekstur silase yang sedikit keras juga menunjukkan bahwa kadar air silase sudah rendah serta tidak terdapat lendir pada silase, dan menunjukkan bahwa silase memiliki kualitas tekstur yang baik. Kojo dkk (2015) menyatakan bahwa silase dapat dikatakan baik apabila tidak memiliki tekstur lembek, tidak berair, tidak berjamur dan tidak menggumpal. Menurut Chalisty dkk (2017) kadar air yang tinggi pada hijauan akan menyebabkan air tirisan menjadi banyak sehingga oksigen dalam silo menjadi meningkat. Hal tersebut dapat menyebabkan silase memiliki tekstur yang lunak, berlendir serta tumbuh jamur yang mengindikasikan silase memiliki kualitas yang buruk.

Tabel 2 menunjukkan bahwa hasil aroma silase berturut-turut yaitu $\mathrm{P} 0\left(3,90^{\mathrm{b}} \pm\right.$ $0,73), \mathrm{P} 1\left(4,02^{\mathrm{b}} \pm 0,83\right), \mathrm{P} 2\left(3,12^{\mathrm{a}} \pm 0,74\right)$, dan P3 $\left(3,02^{\mathrm{a}} \pm 0,70\right)$. Silase P1 menunjukkan aroma yang sedikit asam dan menunjukkan bahwa silase memiliki kualitas yang baik. Aroma silase yang sedikit asam disebabkan karena rendahnya $\mathrm{pH}$ silase. Aroma pada silase berkaitan dengan asam yang dihasilkan selama proses ensilase. Kurnianingtyas, Pandansari, Astuti, Widyawati dan Suprayogi (2012) menyatakan bahwa aroma asam yang dihasilkan oleh silase disebabkan oleh bakteri anaerob yang menghasilkan asam organik. Pada silase P0, P2 dan P3 menunjukkan silase dengan aroma segar dan sedikit asam. Silase dengan aroma segar dan sedikit asam juga menunjukkan kualitas silase yang baik. Lama inkubasi berpegaruh terhadap aroma silase menjadi sedikit asam dikarenakan proses fermentasi yang dapat menghasilkan asam laktat. Zakariah dkk (2015) menyatakan bahwa silase dengan aroma asam segar merupakan silase dengan kualitas yang baik.

Tabel 2 menunjukkan bahwa hasil dari pengujian panelis yaitu 5,00 atau tidak terdapat jamur pada semua perlakuan (P0, P1, P2, P3). Hal tersebut menunjukkan bahwa silase memiliki kualitas yang baik dan proses fermentasi sepenuhnya dalam keadaan anaerob atau tidak terdapat oksigen. Menurut Chalisty dkk (2017) bahwa terdapatnya jamur secara keseluruhan atau sebagian disebabkan oleh bagian permukaan silo yang merupakan tempat pengikatan, masih terdapat kemungkinan proses ensilase yang tidak sepenuhnya anaerob. Kondisi ini menyebabkan silase terpapar oksigen dan jamur dapat tumbuh dengan memfermentasi asam laktat dan karbohidrat mudah larut. 


\section{Nilai pH Silase Rumput Odot}

Hasil pengamatan pada Tabel 3 menunjukkan bahwa $\mathrm{pH}$ tertinggi terdapat pada $\mathrm{P} 0$ yaitu silase dengan waktu inkubasi 0 hari. Hal tersebut dikarenakan pada P0 belum terjadi proses fermentasi sehingga bakteri asam belum bekerja secara maksimal.

Sedangkan $\mathrm{pH}$ silase pada waktu inkubasi 7,14 dan 21 hari berturut-turut yaitu P1 (4,10), P2 (4,13), dan P3 (4,30). Silase P1 dan P2 menunjukkan silase dengan kualiatas sangat baik, sedangkan P3 menunjukkan silase dengan kualitas baik. Siregar (1996) menyatakan bahwa kualitas silase menurut $\mathrm{pH}$ yang dihasilkan yaitu sangat baik $(3,5-4,2)$, baik $(4,2-4,5)$, sedang $(4,5-4,8)$ dan jelek $(>4,8)$. Cepatnya penurunan $\mathrm{pH}$ silase rumput odot diduga dikarenakan penambahan bakteri Lactobacillus plantarum sebanyak 0,6\% yang merupakan jenis bakteri asam laktat. Mugiawati Suwarno dan Hidayat (2013) menyatakan bahwa bakteri asam laktat akan mengubah glukosa atau karbohidrat sederhana menjadi alkohol, asam asetat, asam karbonat dan asam laktat.

Tabel 3. Rataan $\mathrm{pH}$ silase rumput odot

\begin{tabular}{cl}
\hline Perlakuan & Rataan \\
\hline P0 & $6,50 \pm 0,10^{\mathrm{c}}$ \\
P1 & $4,10 \pm 0,10^{\mathrm{a}}$ \\
P2 & $4,13 \pm 0,05^{\mathrm{a}}$ \\
P3 & $4,30 \pm 0,00^{\mathrm{b}}$ \\
\hline
\end{tabular}

Superskrip yang berbeda $\left({ }^{\mathrm{a}-\mathrm{c}}\right)$ menunjukkan perbedaan yang sangat nyata $(\mathrm{P}<0,01)$

\section{Kandungan Nutrisi Silase Rumput Odot}

Berdasarkan hasil analisis statistik kandungan nutrisi (BK, BO, PK, SK, LK) silase rumput odot menunjukkan bahwa dengan waktu inkubasi yang berbeda tidak terdapat pengaruh nyata $(\mathrm{P}>0,05)$ terhadap kandungan $\mathrm{BK}, \mathrm{BO}$ dan $\mathrm{PK}$, tetapi memberikan pengaruh nyata $(\mathrm{P}<0,05)$ terhadap SK dan pengaruh yang sangat nyata $(\mathrm{P}<0,01)$ terhadap LK. Tabel 5 menunjukkan bahwa pada $\mathrm{PO}$ tidak terjadi penurunan atau peningkatan kandungan nutrisi silase. Hal tersebut dikarenakan P0 merupakan perlakuan dengan waktu inkubasi 0 hari dan belum mengalami proses ensilase. Penurunan kandungan nutrisi disebabkan karena terjadinya proses ensilase, sedangkan peningkatan kandungan nutrisi pada LK diduga disebabkan oleh semakin lama proses ensilase maka bakteri asam akan memproduksi asam lemak lebih banyak.

\section{Kandungan BahanKering}

Persentase bahan kering cenderung tinggi terdapat pada P0 yaitu dengan waktu inkubasi 0 hari, sedangkan prosentase bahan kering cenderung rendah yaitu pada P3 dengan waktu inkubasi 21 hari. Hasil penelitian menunjukkan bahwa semakin lama waktu inkubasi maka akan berpengaruh terhadap menurunnya bahan kering silase. Menurut Salim, et al dalam Sandi, Ali, dan Arianto (2012) bahwa pada saat fase aerob terjadi kehilangan bahan kering yang paling besar. Mikroba aerob masih aktif dalam merombak substrat menjadi $\mathrm{CO}_{2}$ dan $\mathrm{H}_{2} \mathrm{O}$ serta panas energi respirasi. Ketika $\mathrm{pH}$ telah asam dikarenakan adanya asam laktat yang diproduksi oleh bakteri asam laktat, maka proses perombakan tadi berhenti dan silase menjadi stabil.

\section{Kandungan BahanOrganik}

Tabel 4 dan 5 menunjukkan bahwa semakin lama waktu inkubasi akan menyebabkan bahan organik menjadi semakin rendah. Santoso dan Hariadi (2008) menyatakan bahwa konsentrasi bahan organik yang tinggi pada silase rumput raja dikarenakan degradasi komponen nutrisi yang rendah selama proses ensilase dibandingkan dengan silase yang lainnya. Kehilangan BK, kehilangan BO juga terkait dengan ketersediaan karbohidrat terlarut yang merupakan komponen organik yang berasal dari BETN. Kandungan BETN yang semakin tinggi seiring dengan umur potong (sampai umur potong 80 hari) akan memacu terbentuknya asam laktat sehingga menyebabkan proporsi BETN menurun. 
Asam laktat dalam ensilase dihasilkan dari komponen bahan organik terutama karbohidrat, sehingga meningkatnya pembentukan asam laktat dan turunnya $\mathrm{pH}$ merupakan indikasi pula bahwa banyak BO yang digunakan untuk ensilase yang selanjutnya merupakan penyebab kehilangan BO.

\section{Kandungan ProteinKasar}

Berdasarkan Tabel 4 dapat diketahui bahwa kandungan protein kasar pada waktu inkubasi 0 hari (P0) yaitu sebesar 11,84\% dan merupakan kandungan protein kasar yang cenderung tinggi dari semua perlakuan. Kemudian kandungan protein kasar pada waktu inkubasi 7, 14 dan 21 hari yaitu $11,81 \%, 11,74 \%$ dan $11,43 \%$.Hasil penelitian menunjukkan bahwa semakin lama waktu inkubasi akan menyebabkan kandungan protein kasar dalam bahan menurun. Hal tersebut diduga karena bakteri proteolitik telah aktif dalam merombak protein yang terkandung dalam bahan. Santoso dan Hariadi (2008) menyatakan bahwa ensilase hijauan baik secara langsung maupun setelah pelayuan, akan berlangsung proses proteolysis secara kontinyu dalam waktu 24 jam. Selama periode tersebut, kandungan protein dapat mengalami penurunan sebanyak $0,8 \%$ hingga $0,6 \%$. Kandungan protein kasar dengan waktu inkubasi 0,7,14 dan 21 hari tidak menunjukkan selisih yang tinggi. Hal tersebut diduga karena terdapatnya bahan aditif yang ditambahkan yaitu berupa molasses dan bakteri Lactobacillus plantarum.

\section{Kandungan SeratKasar}

Berdasarkan Tabel 4 dapat diketahui bahwa kandungan serat kasar tertinggi yaitu pada perlakuan 0 hari (P0) sebesar 23,94\%. Namun kandungan tersebut hampir sama dengan P1 yang di inkubasi selama 7 hari yaitu sebesar $23,74 \%$. Silase pada P2 dan P3 memiliki kandungan serat kasar sebesar 23,23\% dan 22,90\%. Berdasarkan hasil penelitian, dapat diketahui bahwa kandungan SK terendah terdapat pada P3, sedangkan kandungan SK tertinggi terdapat pada P0. Hal tersebut diduga disebabkan oleh semakin lama waktu inkubasi, maka aktivitas bakteri selulolitik yang mendegradasi lignin yang terkandung pada silase akan semakin meningkat dan menyebabkan turunnya kandungan serat kasar. Menurut Polakitan dan Kairupan (2011) bahwa rumput gajah mini atau rumput odot memiliki struktur serat yang tidak begitu kuat didinding sel, sehingga hal ini menyebabkan banyaknya karbohidrat yang mudah tercerna. Lubis dalam Anjalani dkk (2017) mengatakan bahwa penurunan kadar SK akan berpengaruh baik pada kualitas silase karena SK yang terlalu tinggi dapat menurunkan kecernaan bahan pakan akibat terganggunya proses pencernaan zat-zat lain di dalam pakan. Hal ini disebabkan karena untuk mencerna serat kasar dibutuhkan banyak energi.

Tabel 4. Kandungannutrisisilaserumputodotpadamasing-masingperlakuan

\begin{tabular}{llllll}
\hline Perlakuan & \multicolumn{5}{c}{ Kandungan nutrisi (\% BK) } \\
\cline { 2 - 6 } & BK & BO $^{*}$ & PK $^{*}$ & SK $^{*}$ & LK $^{*}$ \\
\hline P0 & $15,74 \pm 0,37$ & $82,66 \pm 0,02$ & $11,84 \pm 0,38$ & $23,94 \pm 0,23^{\mathrm{b}}$ & $1,16 \pm 0,11^{\mathrm{a}}$ \\
P1 & $15,69 \pm 0,18$ & $82,44 \pm 0,89$ & $11,81 \pm 0,13$ & $23,74 \pm 0,51^{\mathrm{a}}$ & $2,23 \pm 0,14^{\mathrm{b}}$ \\
P2 & $15,62 \pm 1,01$ & $82,45 \pm 0,78$ & $11,74 \pm 0,13$ & $23,23 \pm 0,31^{\mathrm{a}}$ & $2,51 \pm 0,21^{\mathrm{b}}$ \\
P3 & $15,03 \pm 0,23$ & $82,31 \pm 0,71$ & $11,43 \pm 0,55$ & $22,90 \pm 0,48^{\mathrm{a}}$ & $2,74 \pm 0,13^{\mathrm{b}}$ \\
\hline
\end{tabular}

(*) berdasarkan $100 \% \mathrm{BK}$

${ }^{\mathrm{a}, \mathrm{b}}$ superskrip yang berbeda pada kolom SK menunjukkan perbedaan yang nyata $(\mathrm{P}<0,05)$

${ }^{a, b}$ superskrip yang berbeda pada kolom LK menunjukkan perbedaan yang sangat nyata $(\mathrm{P}<$ $0,01)$ 
Tabel 5. Persentase penurunan kandungan nutrisi silase rumput odot

\begin{tabular}{llllll}
\hline Perlakuan & \multicolumn{5}{c}{ PenurunanKandungan Nutrisi (\%)* } \\
\cline { 2 - 6 } & BK & BO & PK & SK & LK \\
\hline P0 & 0 & 0 & 0 & 0 & 0 \\
P1 & 0,97 & 1,24 & 1,19 & 1,79 & $-90,49$ \\
P2 & 2,07 & 2,31 & 2,81 & 4,94 & $-111,22$ \\
P3 & 5,80 & 6,19 & 9,10 & 9,92 & $-123,31$ \\
\hline
\end{tabular}

* Berdasarkan waktu inkubasi 0 hari (P0)

-Tanda (-) menunjukkan peningkatan pada kandungan Lemak Kasar

\section{Kandungan LemakKasar}

Berdasarkan rataan LK pada Tabel 4, dapat diketahui bahwa prosentase kandungan lemak kasar berturut-turut yaitu P0 1,16\%, P1 2,28\%, P2 2,51\%, dan P3 2,74\%. Hal tersebut menunjukkan bahwa semakin lama waktu inkubasi silase rumput odot dapat meningkatkan kandungan lemak dalam silase. Selain itu, diduga dikarenakan semakin lama proses inkubasi menyebabkan terjadinya perombakan karbohidrat menjadi asam lemak, sehingga dapat meningkatkan kandungan lemak. Hal tersebut dijelaskan pula oleh Hidayat (2014) bahwa dalam proses ensilase, karbohidrat yang berasal dari tanaman dan aditif akan dirombak menjadi asam lemak terbang yaitu asam laktat, asam asetat, asam butirat, asam karbonat serta alkohol dalam jumlah yang kecil.

\section{Nilai Fleigh Silase Rumput Odot}

Nilai fleigh atau fleigh point merupakan nilai yang digunakan untuk menentukan kualitas fermentasi pada silase ditinjau dari nilai bahan kering (BK) dan $\mathrm{pH}$. Hasil nilai fleigh silase rumput odot disajikan dalam Tabel 6.
Tabel 6. Rataan fleigh point silase rumput odot

\begin{tabular}{cc}
\hline Perlakuan & Rataan \\
\hline P0 & $-23,52 \pm 4,65^{\mathrm{a}}$ \\
P1 & $72,37 \pm 3,68^{\mathrm{b}}$ \\
P2 & $70,89 \pm 2,07^{\mathrm{b}}$ \\
P3 & $63,06 \pm 0,46^{\mathrm{b}}$
\end{tabular}

${ }^{\mathrm{a}-\mathrm{b}}$ superskrip menunjukkan perbedaan yang sangat nyata pada setiap perlakuan $(\mathrm{P}<0,01)$

Berdasarkan hasil penelitian menunjukkan bahwa P0 memiliki fleigh point terendah dibandingkan dengan perlakuan yang lainnya. Fleigh point pada P0 menunjukkan nilai $-23,52$ dan tergolong memiliki kualitas fermentasi yang sangat buruk. Hal tersebut dikarenakan pada $\mathrm{P} 0$ belum terjadi proses fermentasi (0 hari) serta tingginya $\mathrm{pH}$ sebesar 6,5 dan BK sebesar 15,74\%. Berdasarkan Bakrie dkk (2014) menyatakan bahwa nilai fleigh dihitung berdasarkan formula Killic (1984) yaitu $\mathrm{NF}=220+(2 \times \% \mathrm{BK}-15)-(40 \times \mathrm{pH})$. Jika fleigh point sebesar 85 - 100 maka nilai kualitas fermentasi silase adalah sangat baik. Jika fleigh point sebesar 60 80 maka kualitas fermentasi silase adalah baik. Jika fleigh point menunjukkan angka 55 - 60, maka silase memiliki kualitas fermentasi sedikit baik. Silase dengan nilai 25 - 40 memiliki kualitas fermentasi sedang dan silase dengan fleigh point $<20$ maka tergolong memiliki kualitas fermentasi sangat buruk. Berdasarkan Tabel 6 dapat diketahui bahwa nilai fleigh yang tertinggi yaitu P1 sebesar 72,37 dan 
tergolong memiliki kualitas fermentasi yang baik (60-80). Hal tersebut menunjukkan bahwa pada waktu inkubasi 7 hari silase sudah memiliki kualitas fermentasi yang baik serta ditunjukkan dengan tingginya $\mathrm{BK} \quad(15,69 \%)$ dan rendahnya $\mathrm{pH}(4,10)$. Tinggi atau rendahnya fleigh point bergantung pada nilai $\mathrm{BK}$ dan $\mathrm{pH}$ silase, semakin tinggi nilai $\mathrm{BK}$ dan semakin rendah nilai $\mathrm{pH}$ maka akan membuat fleigh point juga semakin tinggi.

\section{KESIMPULAN}

Perlakuan terbaik yaitu ditunjukkan pada P1 dengan waktu inkubasi 7 hari yang memiliki karakteristik fisik (warna, aroma dan tekstur) silase yang baik, $\mathrm{pH}$ yang rendah $(\mathrm{pH} 4,10)$ serta penurunan kandungan nutrisi yang rendah (BK $15,69 \%$, BO 82,44\%, PK 11,81\%, SK $23,74 \%$ dan LK 2,23\%). Perlu dilakukan penelitian lebih lanjut mengenai silase rumput odot secara in vivo dengan bahan aditif berupa molasses dan Lactobacillus plantarum untuk mengetahui respon secara langsung dari ternak.

\section{DAFTAR PUSTAKA}

Anjalani, R., Silitonga, L., \& Astuti, M. H. (2017). Kualitas silase rumput gajah yang diberi tepung umbi talas sebagai aditif silase. Jurnal Ilmu Hewani Tropika, 6(1), 29-34.

Bakrie, B., Sastro, Y., Bahar, S., Sente, U., \& Andayani, D. (2014). Perbandingan efektifitas penambahan onggok atau tepung sinkong dalam pembuatan silase limbah sayuran. Buletin Pertanian Perkotaan, 4(1), 1-12.
Chalisty, V., Utomo, R., \& Bachruddin, Z. (2017). Pengaruh penambahan molasses, lactobacillus plantarum, trichoderma viride \& campurannya terhadap kualitas total campuran hijauan. Buletin Peternakan, 411(4), 4311-4318.

Hidayat, N. (2014). Karakteristik \& kualitas silase rumput raja menggunakan berbagai sumber \& tingkat penambahan karbohidrat fermentable. Jurnal Agripet, 14(1), 42-49. https://doi.org/10.17969/agripet.v14i1.1204

Kaiser, A., \& Piltz, J. (2004). Feed testing: assesing silage (assesing s). New Soulth Wales: NSW Departement of Primary Industries \& dairy Australia.

Kojo, R., Rustandi., Tulung, Y. R., \& Malalantang, S. (2015). Pengaruh penambahan dedak padi \& tepung jagung terhadap kualitas fisik silase rumput gajah. Jurnal Zootek, 35(1), 21-29.

Kurnianingtyas, I., Pandansari, P., Astuti, I., Widyawati, S., \& Suorayogi, W. P. (2012). Pengaruh macam akselerator terhadap kualitas fisik, kimiawi \& biologi silase rumput kolonjono. Tropical Animal Husbandry, 1(1), 7-14.

Mugiawati, R., Suwarno, S., \& Hidayat, N. (2013). Kadar air \& pH silase rumput gajah pada hari ke-21 dengan penambahan jenis additive \& bakteri asam laktat. Jurnal Ilmiah Peternakan, 1(1), 201-207.

Naif, R., Nahak, O. R., \& Dethan, A. A. (2016). Kualitas nutrisi silase rumput gajah (pennisetum purpureum) yang diberi dedak padi $\&$ jagung giling dengan level berbeda. JAS, 1(1), 6-8. 
Polakitan, D., \& Kairupan, A. (2011). Pertumbuhan \& produktivitas rumput gajah dwarf (Pennisetum purpureum cv. Mott) pada umur potong berbeda.

Sandi, S., Ali, A. I., \& Arianto, N. (2012). Kualitas nutrisi silase pucuk tebu (saccarum officinarum) dengan penambahan inokulan effective microorganism-4 (EM-4). Jurnal Peternakan Sriwijaya, 1(1), 1-9.
Santoso, B., \& Hariadi. B.Tj. (2008). Komposisi kimia, degradasi nutrien $\&$ produksi gas metana in vitro rumput tropik yang diawetkan dengan metode silase \& hay. Media Peternakan, 31(2), 128-137.

Siregar, S. (1996). Pengawetan pakan ternak. Jakarta: Penebar Swadaya.

Zakariah, M., Utomo, R., \& Bachruddin, Z. (2005). Pengaruh campuran lactobacillus plantarum \& saccaromyces cerevisiae terhadap kualitas organoleptik, fisik \& kimia silase kulit buah kakao. Buletin Peternakan, 39(1), 1-8. 